$(2939)$

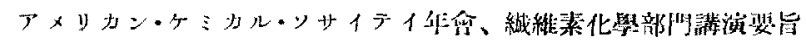

\title{
アメリカン・ケミカル・ソサイティ年會 纎維素化學部門講演要旨
}

(Baltimore, Maryland, 4 月 $3 \mathrm{H} \sim 7 \mathrm{H}, 1964$ )

田川博 譯

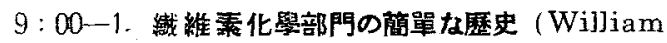
o. Kenyon.)

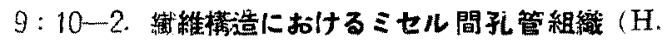
Mark)

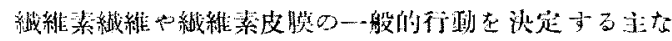

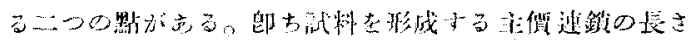

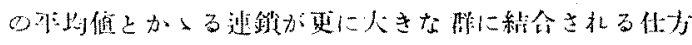
のニつでまる。第一の墨に絛しては渗透厎、䉼度、特に

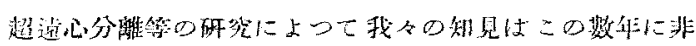

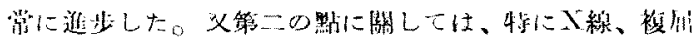

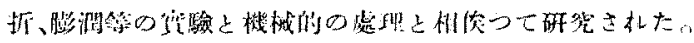

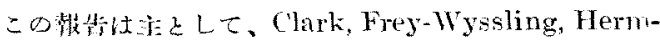
ans, Kratky, Mark, Nisum, Shlumek の研然に上る。

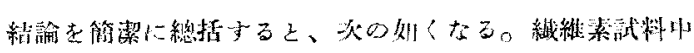

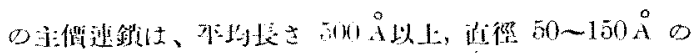

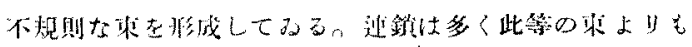

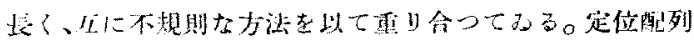

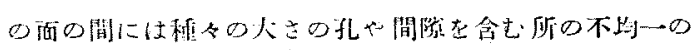

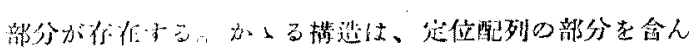

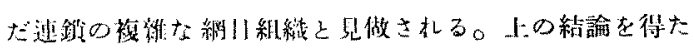

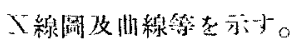

\section{9:30-3，多糖類の分子の大さを沠定する新しい方法}

(E. N. Lasserttre, M. L. Wolfrom, John C. Snowden, and D. R. Myers)

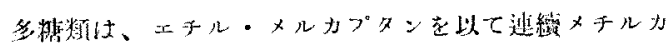

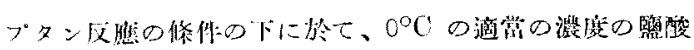

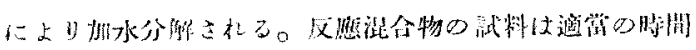

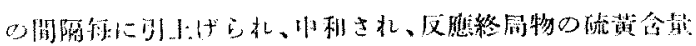

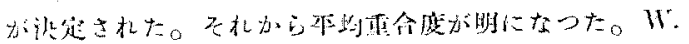

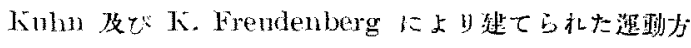

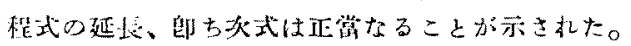

$$
\frac{d-1}{d}=\frac{M-1}{d t} e^{-k l}
$$

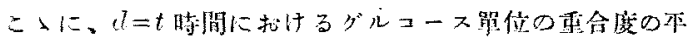

均值、 $K=$ 比性数、

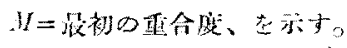

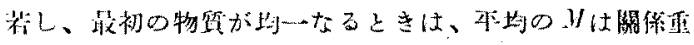
量平㱒倠上密接に比例する。

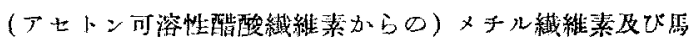

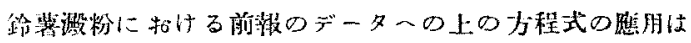

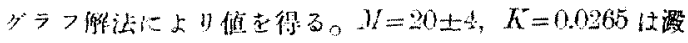

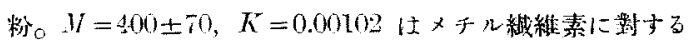
低である。

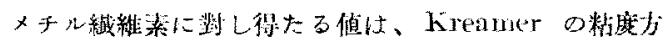

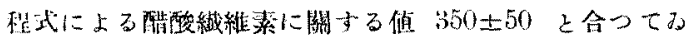
zo

\section{9: 50-4. アルカリ溶液中の峞水化物の行動（Wm.}

\section{Lloyd Evans.)}

I. ーキッース、ペントース、グリセりンアルル゙ヒド、 デヒドロキシアセトンは步性カりの水溶液に上り作用さ れて、多量に学酸が弪成される。天の量はアルカリ及ビ

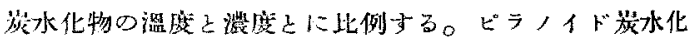

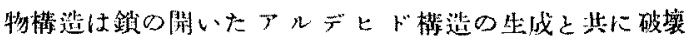

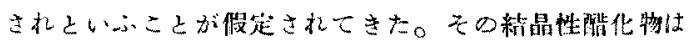
留还多量に乳酸を生げることが知ら机た、この量が述

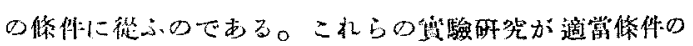

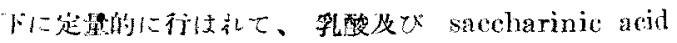

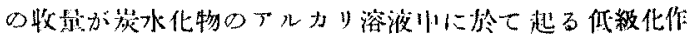
川丁の分子们機㭗の、に光明を敃げかけた。 


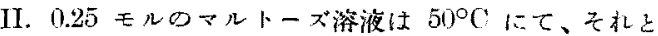

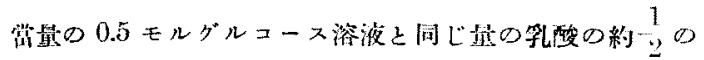

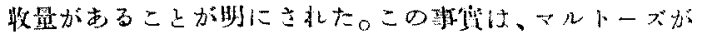
ターダルコシードーメリスローズに分解し、そ扎が顼次に アルカリ溶腹にて加承分艧してそのテトローズ及一キッ

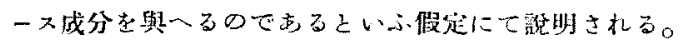

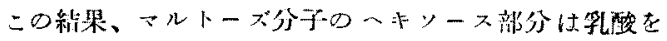

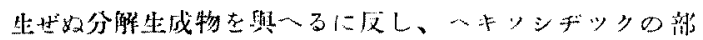

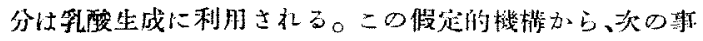

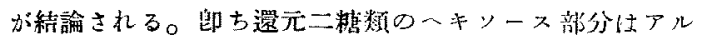

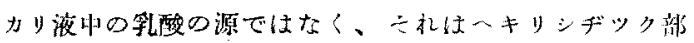

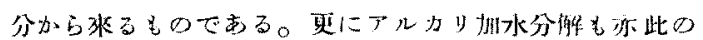
少式に念ま机るる假定される。

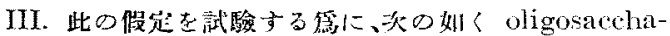
ride の組合せが始めて合成された。跳ち ghuouilodihydroxyactone pentaaceate 及づ cellobiosidodihydroxyacetone octaacetate, \& galactosidodihydroxyacetone pentaacetate $Z^{2}$ lactosidodihydrox yacetone octaacetate glncosidodihylroxyaceton pentaacetateの二-20荻水化物の成分は cellobiosidodihydro-

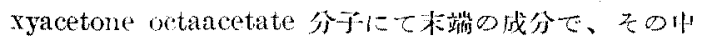

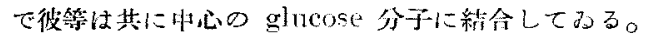

同㥞の事方: galactosidodihydroxyacetone pentaacetate $z$ lactosidodiliydroxyaceton: octaacetate s

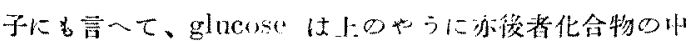
心分子である。II・に批ける将へに合ふためには、cello-

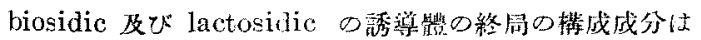
glucosidic 2 galactosidie $の$ 化合物と间 乳酸を與人るぶきである。

之は嗐驗的に正しと證明された。

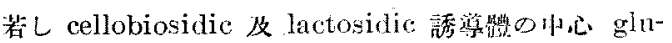
cose 部分がアルカリ溶液中にて乳酸在與へるゃうに反然 するとせば、此の關探は㫮ではないであるら。

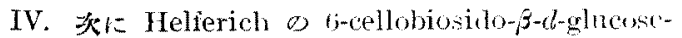
hendecaacetate 及び我↔の新しく合成した 6-malrosi-

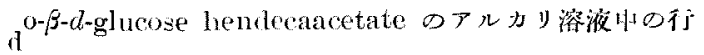

動につき研究が行は札た。

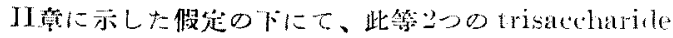

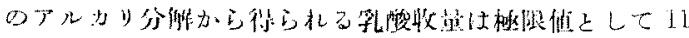

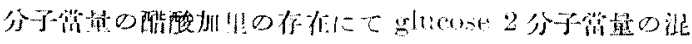

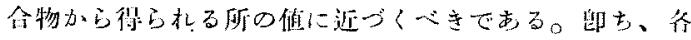

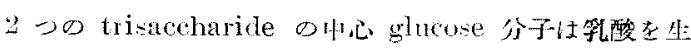

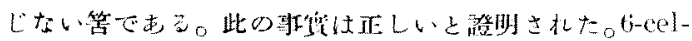
lobiosidomanose, (j-ualtusidonamnose ßð゙ (i-lac-

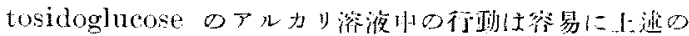
假定に作り派昆されうる。

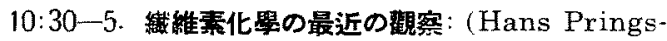
heim.)

11:00-6. National Bureau of Standardにおけ

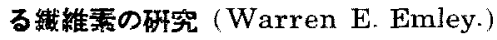

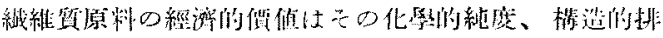

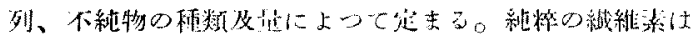

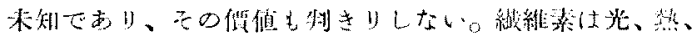

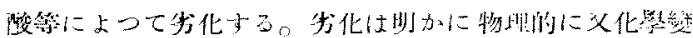

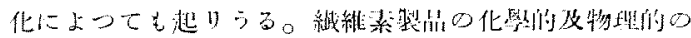

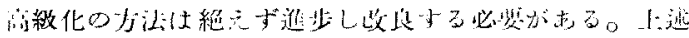

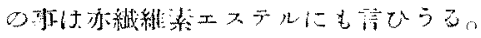

11:15-7. Bureau of Agricultural Economics, U.S. Department of Agriculture による木綿市湆に

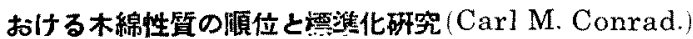

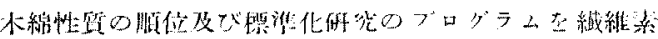

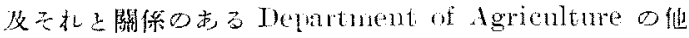

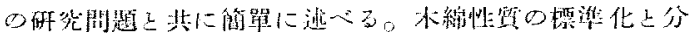

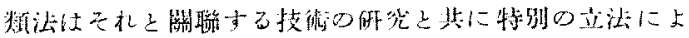

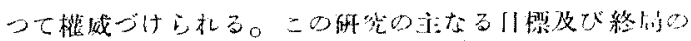

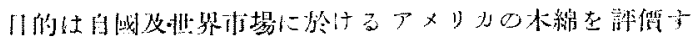

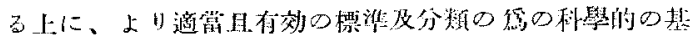
礎を舆一ることでする。

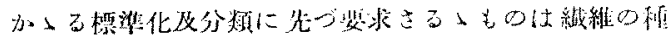

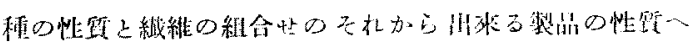

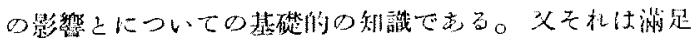

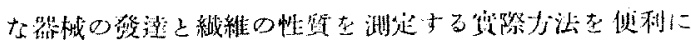




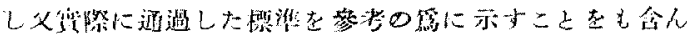

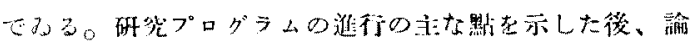

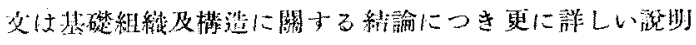
をしてみる。

\subsection{0-8. 精製木材維維素 (George A. Richter)}

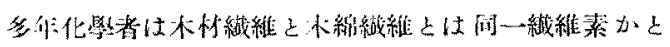

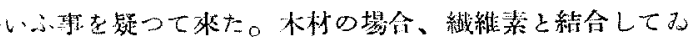

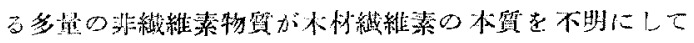
隶た。更に、二次的のリダニン、ベントザン、その他を、䋐

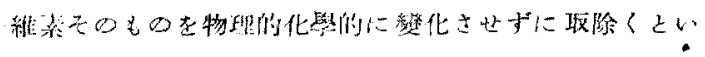

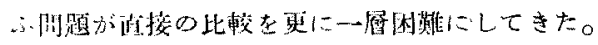

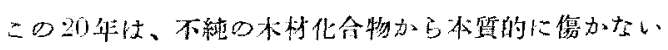

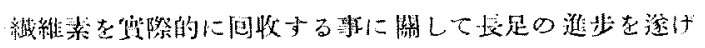

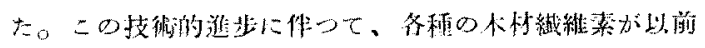

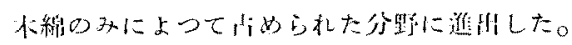

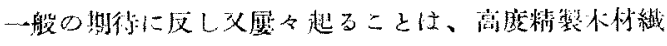

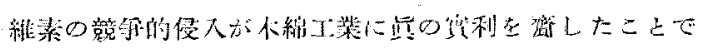

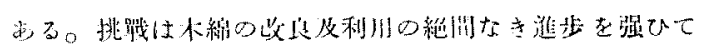

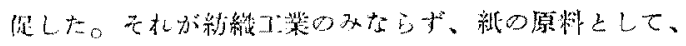

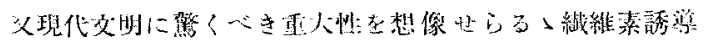
䊁の原料をして絶えず受入北ミ北てるる。

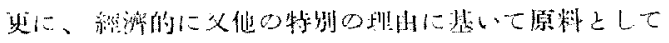

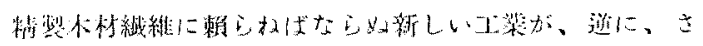

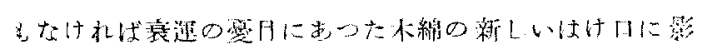
器然與一た。

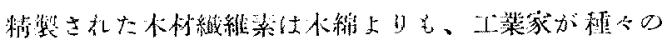

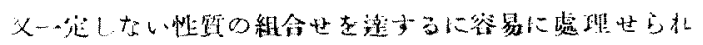

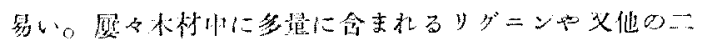

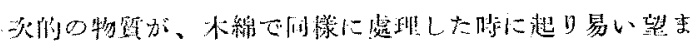

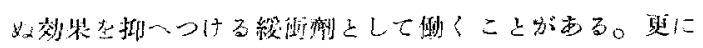

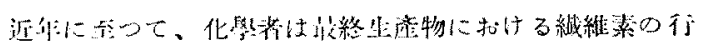

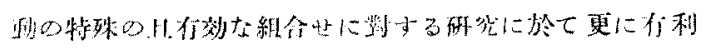

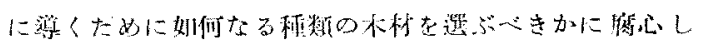
$\tau \partial_{\alpha}$

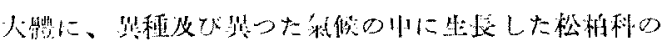

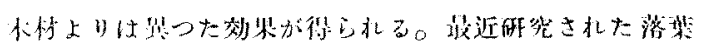

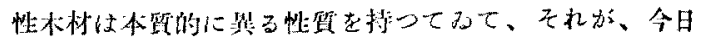

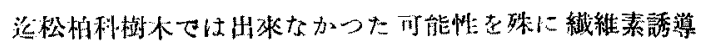

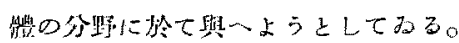

\section{2:20ー9. 種んの工業用バルプの化照的及物理的性斦}

\section{(S. I. Aronoysky \& E. C. Dryden.)}

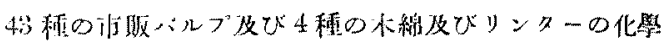

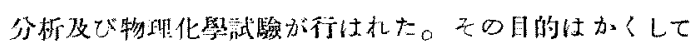

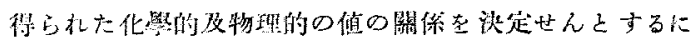

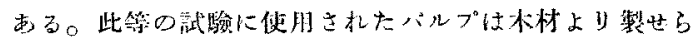

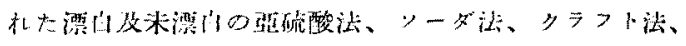

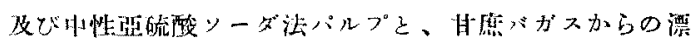

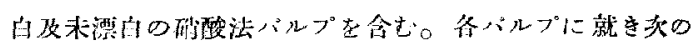

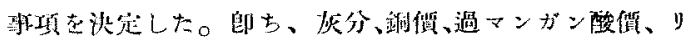

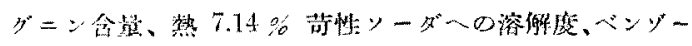

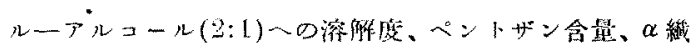

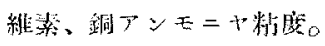

分析の綃果仗、表及间に表はされ、種内の整のバルプ

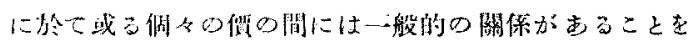

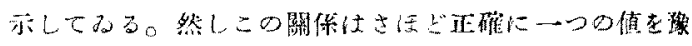
洲しうる程十分ではない。

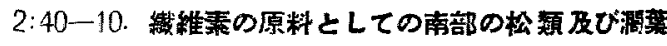

樹 (Charles Carpenter \& Frank McCall.)

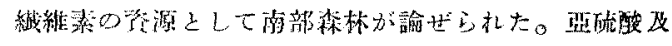

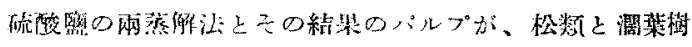

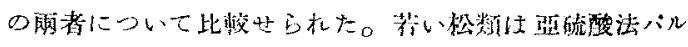

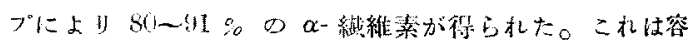

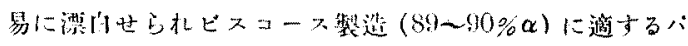

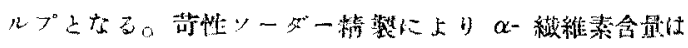

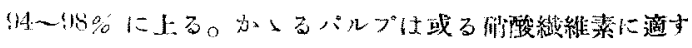

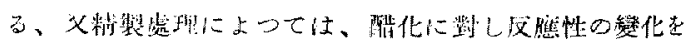
示高。

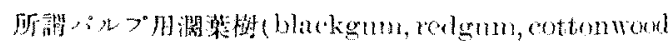

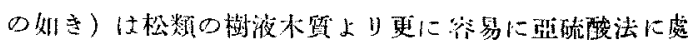

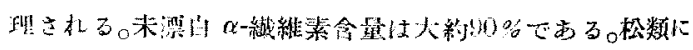

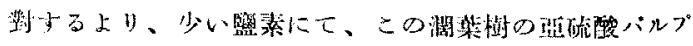

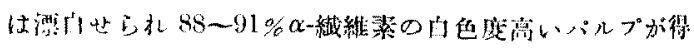




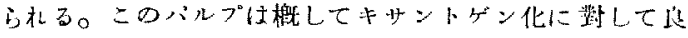
好な反然性を示し、特份のビスコースの性毁を有す。苗

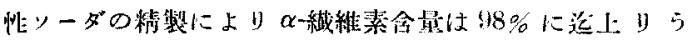

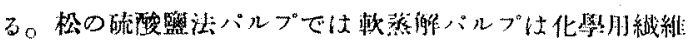

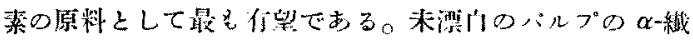

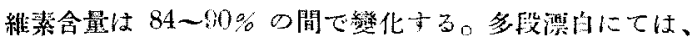

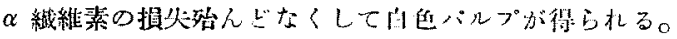

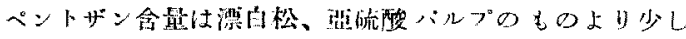

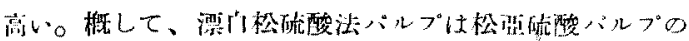

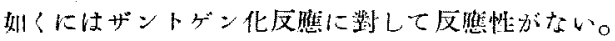

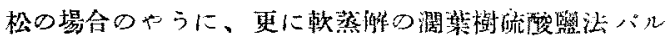

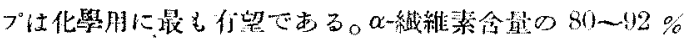

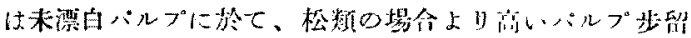
にて得られる。多段洒白により て光澤あるパルプが猜られる。ペントザン念量は非常に

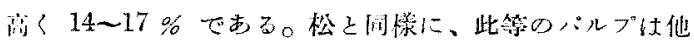

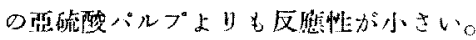

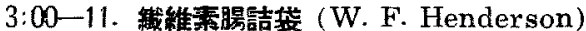

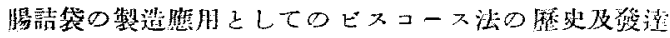

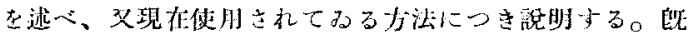

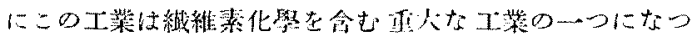
たし、更に闪粼の饭装として租照となる迎命にする。

3:15一-12. 縃緣物としての緎維表の利用 (G. T. Kohman.)

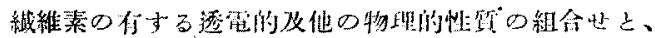

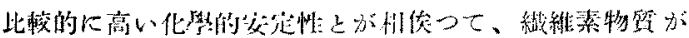

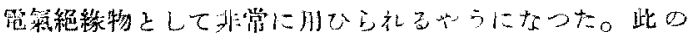

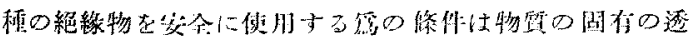

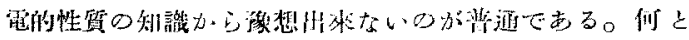

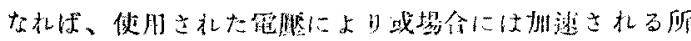

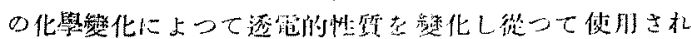

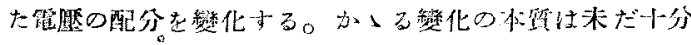

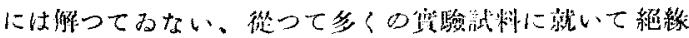

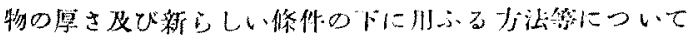

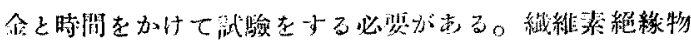

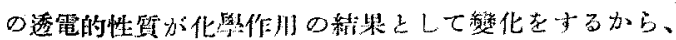

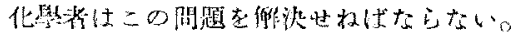

报もはげしい作用の條件は impregnated lapex ca-

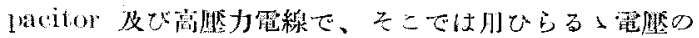

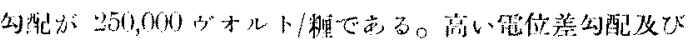

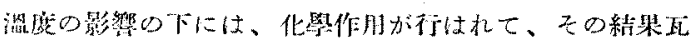

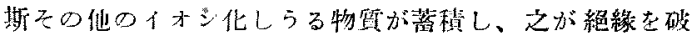

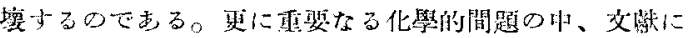

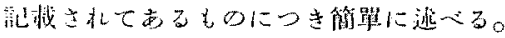

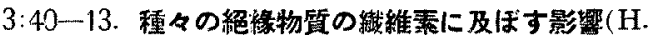

C. P. Weber.)

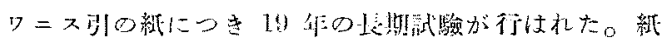

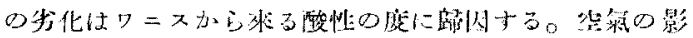

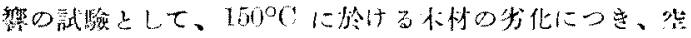

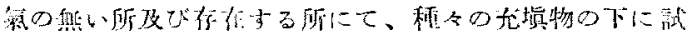

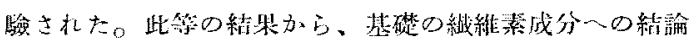
在街た。

\section{4:00-14. 絕緣紙の灰分の反鷹 (D. A. McLean)}

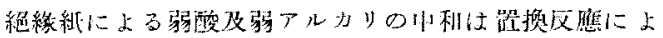
り䛦明されることが明になった。これらの反隼は同柡に

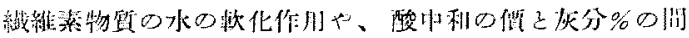

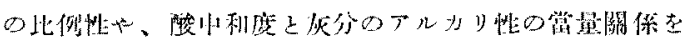

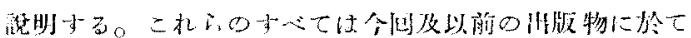
苏さ机た。

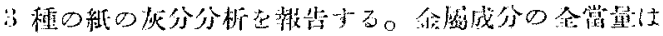

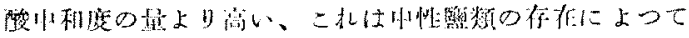

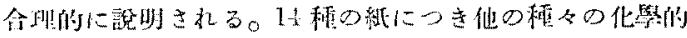
データが與いら扎る。

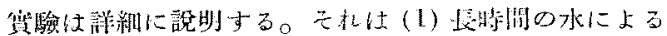

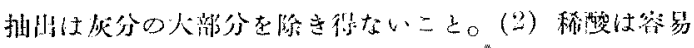

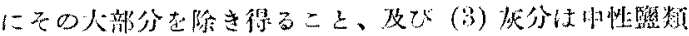

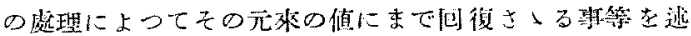
バる。

9:00-15. リグニンの椎造 (Harold Hibbert \& $\mathrm{Co}^{\circ}$ Workers.)

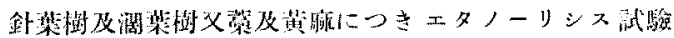
を行ひし精榡、アルュール抽物の小に水可溶性のェタ 


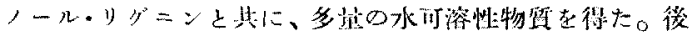

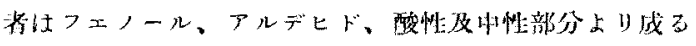
ことが明になつた。

仕沸點〉ェノ一ルは $\alpha$-hydroxypropiovanillone 及 ア: $\alpha$-ethoxypropiosyringone のエチルメーテルなるこ

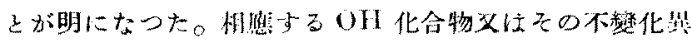

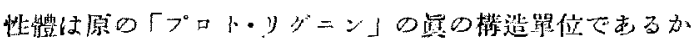

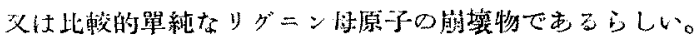
後者の植物に批ける合成は炏の3法の1つとして生越す

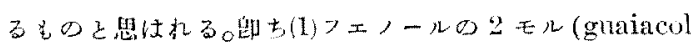
及女y 1,3-pyro-gallol dimethyl ether) onethyl gly oxyl の dimer 之の維合に上る。(2) 同じフェノールの 低々が一分于の Methyl glyoxal 々の緛合により、天の 維来各\& hydroxypropioranillone 及び hydroxylom Iimsyringone o dimerisation 加起ة。(3) vanillin 又は syringic aldehyde が条々 acetaldehyde と䓏合し

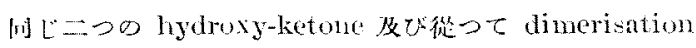
在其点。

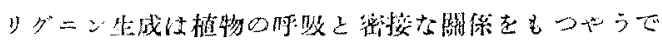

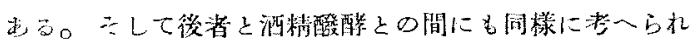
る。ナロマッタ・アルデヒド (vanillin, syringic

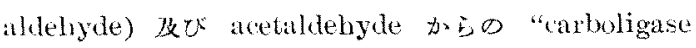
"Yuthesis" D絬果として起るリダニン生成の川能性に 龄して洼䉥が向けられた。

澖藮澍よりのアルデヒド暗分は syringyl 及び guai-

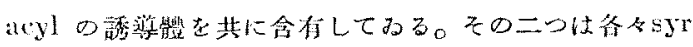

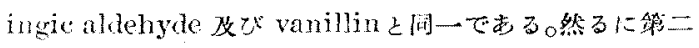
のsyringyl 話酎體は明に syringoylacetaldehyde て かる。假定的に、此等のアルデヒド加 dimeric protolignin の旗物として生成さ扎た。

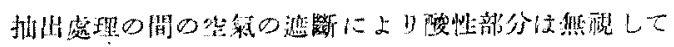
よい程少い。中性部分は研究中でする。

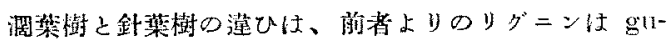
aiacyl 及 syringyl 拱老古つに反L、後者にはguaiacyl

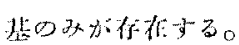

リダニン除生の温利なな七チレーション法の使几によ

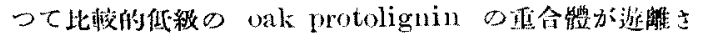

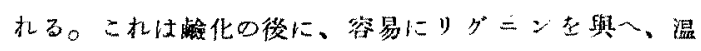

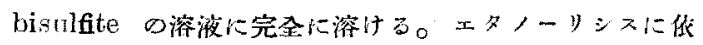
り、遊碓さ扎た acetylated oak ligninは大部分か上逃

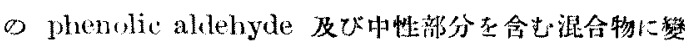
化する。程利に抽州された acetylated uak lignin の俏

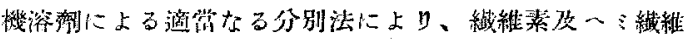
絭老势際に念まない acetylated oak lignin をとり出寸 ことも可能で志る。 $\alpha$-hydroxypropionanillon 老稀陵

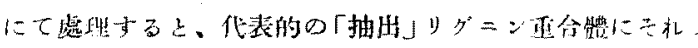

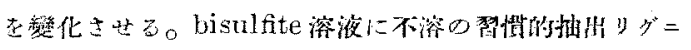
ンはホソンを以て處理することにより可溶とすし得る。

レのデータにより明に制ることは、基本的の protoli-

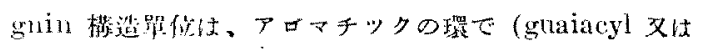

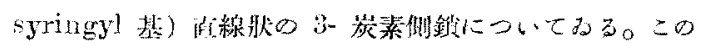
後者は hydroxy-ketone の存在によつて特徽づけられ

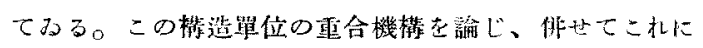

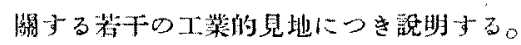

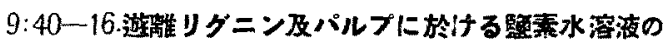

作用 (E. V. White, T. N. Swartz, Joseph L. McCarthy, and Harold Hibbert.)

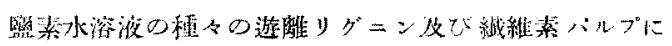

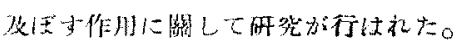

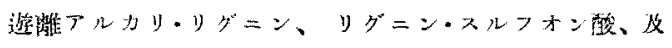
でクラフトリダ=ンはンーダバルプ及びタラフトハルプ

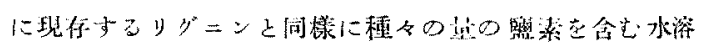

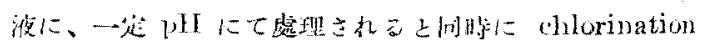

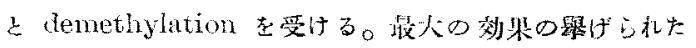

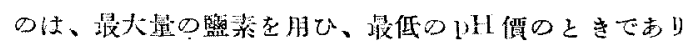

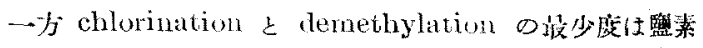

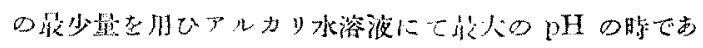

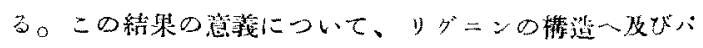

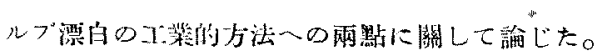

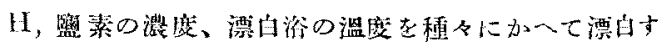

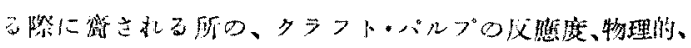

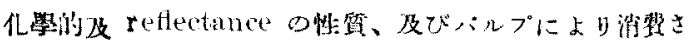




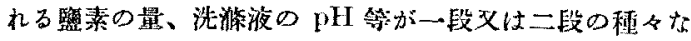
る漂白條件に於て研筧された。

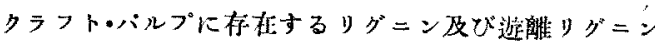
の漂白液との反隼は次の二つの相より成ると舁は机る。 (a) 2 分間に完了する「速なる」反焦る、(b) 漂白鼠䦎 を通じて行はれる「緩慢なる」反隼で、之は監素の水溶 液の自己分解示示時の数學式

$$
d x / d t=K(a-x)^{2}
$$

と同一式によつて進行する。多分、「速なる」反脽による

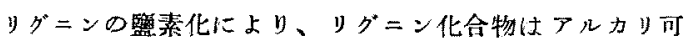
溶性になる。可溶度は明に水洗液のアルカリ性の增於に 㻜つて捪加する。漂白バルプの性質は研然された筑数の

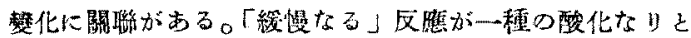
考へると、その比較度は㵶維素及りグニン各なに關して、

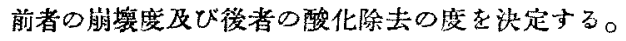

\section{0:10-17. 稙々の dextran の檴造に關する最近の}

進步 (E. C. Fairhead, W. L. Hawkins and Harold Hibbert.)

dextran はバクテリヤ性多糖数の一般分類に曆する。 この多糖類の種に 3 つの代表がある。卸ち Dextrans I 及ư II \& glucose substrate DEK Lenconostoc mesenteroides の継つた㮔によつて合成さるる名のと、 Dextran III は同じ substrate に Jenconostoc dextaniensにより合成される。各々 1:6の位賢に䥊のある glucose anhydride 唯位加成つてみる。

Dextran I は、そ机が自然に生战する Pentosanゃ

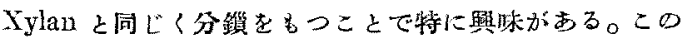
型の畨造は、多糖類のメチレイションの一般的の方法之、

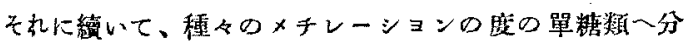

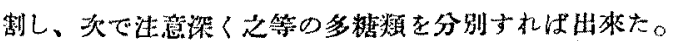
かくの如くして、Dextran I は tetramethyl methylglucoside, trimethyl methylglncoside, 双び dimethyl methylglucoside t $1: 3: 1$ の制合にて 生ずることが明 にされた。

加く比較的各量に生子る dimethyl met]ylglucoside

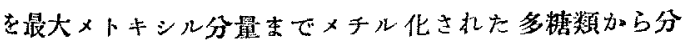

䧼することは、Aimethyl methylghcolyranose 唯仿

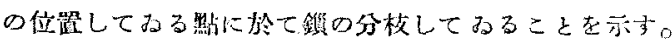
この dimethyl methylglucose の留際の樣相について

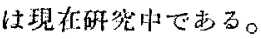

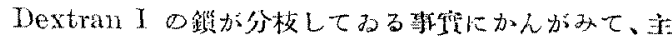

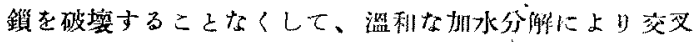
環老破る試み少行は机た。一つのかかる筑瞼による上、 低乘化した多粮類が分睢した。9〜11の glucopyranose

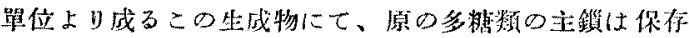
されてるることが示された。

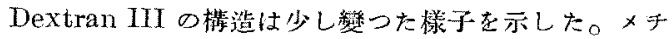

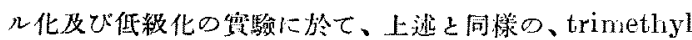
methylghucoside が这生坆物孔して得られたが、 dext ran $D$ 重量o $7.7 \%$ D dinethyl methylghcoside が得ら扎た。具、微项の tetramethyl methylglncose

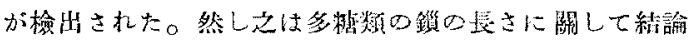
を与る程に定煋的に行は机なかつた。 Dextran I 口埸合

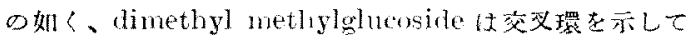
उ。

10:40-18. 長錎の Polyoxyethylene glycol の合成 及びその粘度と沈渥性の重合度との數率的關係(Reid，G Fordyce, Edwin L. Lovell, asd Harold Hibbert.) こ扎は純粹な均一の面顀高等合物の合成を同時にその 溶液の粘度及沈搌性を取报つた

籍 1 論文は一般式 $\mathrm{HO}(\mathrm{CH}, \mathrm{CH}, \mathrm{O}) \times \mathrm{H}$ の Polyoxy ethylene glycols $D$ 合成老 Williamson ether 合战の 方法により行つたこと老速でたるこでは Polyglyeol の $2 モ ル の$ monosodium salt は 1 モの適賞のdichlor 化 合物と㠜綰してるる。

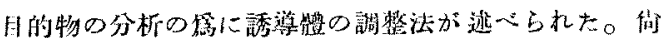
Polyoxyethylen glycol の純度在調へた。6-, 18-, 级42D Polyoxyethylen glycol（分子量夫夕 282,810 及 18 66）D合成党㸃べる。

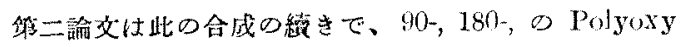

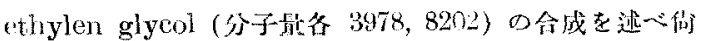
純庭をも調心゙た。 


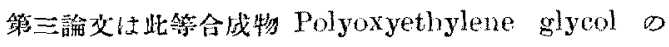

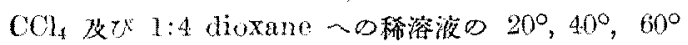

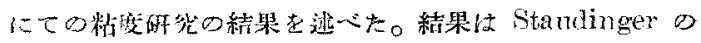
粘度武

$$
\frac{\eta_{s p}}{c}=K_{m} M
$$

により检された。この式をゃゃ学犻した式が提案された。

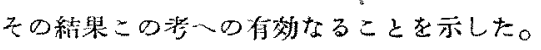

第四諭父は土ーテルによりメタノール溶波加らこ机ら のグリコールの证澱性走定量的に述へた。各グリコール

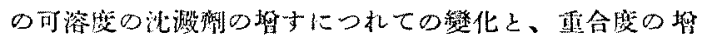

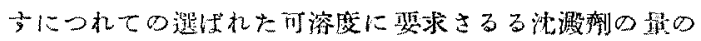
增加が共に起へられる。

此等の結墺は高重合 Polystyren についての Schnlz

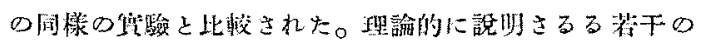

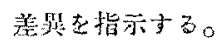

\section{1:20-19. 天然リグニン I. その分離と Methylati-} on. (F. E. Brauns.)

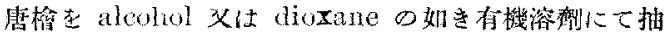

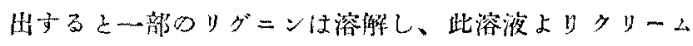

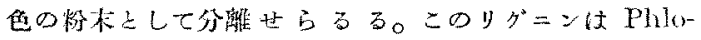
roghuinol-hydrochloric acid $及 2 x$ Phenol-hydrochloric acid 上代表的のック゚ニン呈色又留をする。これに

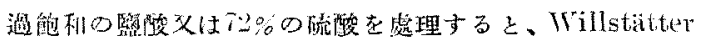
及び Klasson のリグニンに似たリグニンに變化する。 この天然りダニンを diazomethane にて×チル化する そ、部分的にメチル化さ机た天然りグニンを白色粉来る

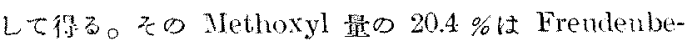
rgりグニンか Diazomethaneにて×チル化されて得ら

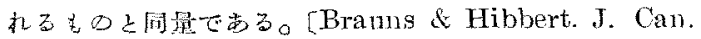

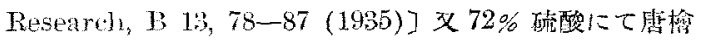
より分磞されたりグニンを Diazomethaneにてメチル 化したるめ上同橙である〔Brawns \& Branns; Ind. Eng. chem. 30,779 (1938) J。部分的×チル化された火

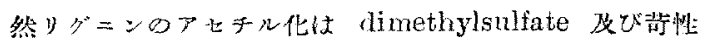
亚洼にて×チル化しらる所の他の $-\mathrm{OH}$ 基の存在走示 してかる。

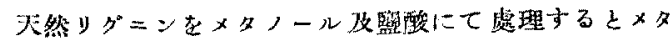

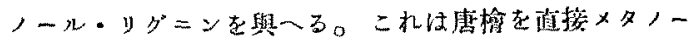

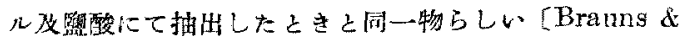
Hibbert, J. Can. Research, B 13, 28-34 (1935)]。

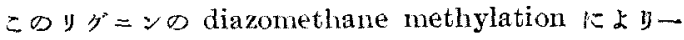
部メチル化されたメタノール・リダニンを得る。之は文 diazomethane-methyl 化さ札た天然りグニン圭メタ，

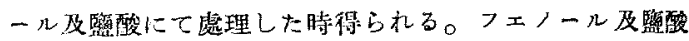
にては Methoxyl 含显が 11.5\%のフェノール・リグニン 加得占机る。之仕 Frendenberg一yダニンよりの phenol-lignin \&同一である。 Bnckland, Branns \& Hibbert," J. Can. Research, B 13, 61-77 (1935)]。

文 thioglycolic acid 及毙酸にては Methoxyl 含量 $10.5 \% 0$ thioglycolic acid lignin t5る。後者估㨁接 磨錸上り製した thioglycolic acid lignin と同一らし yo [Holmberg, Ing. Vetenskaps, Akad. Handl. $103,1-75(1930)]_{0}$

天然りグニンは人く酸性琶䂱酸ソーダに完溶である。

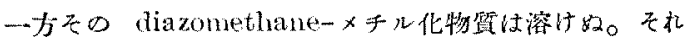

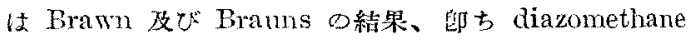
メチル化された wood meal はハルプ化し得好上いふ，考 つと一致することになる。

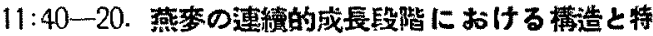
にリグニン生成との關係 [Max Phillips, M. J. Gross B. L. Davis, \& H. Stevens.]

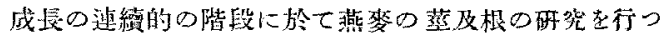

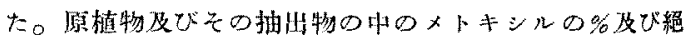

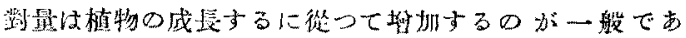
る。タロス・ビバン䋐維䇣、政維菜、 vronic acid, y グ

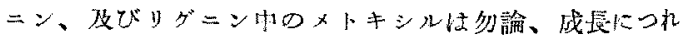

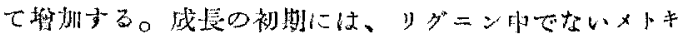
シルは、全整国結合×トキシルの9として表はされ、む しろかな日高いが、植物の成韭已其に之は堿少する。植 物が践維素、ペントザン文はペクチンよりりグニン荅

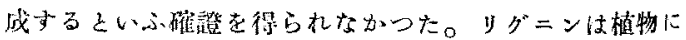
より调接に glucose が sucrose から合成されるのでは 
ないかといふ提䓩在する。リグニン合成の初甽に算つて は、加水分解、酸化、還元及㧤水等の際に岸水化物の分 裂の行程として生成される因く結合してるるメトキシル

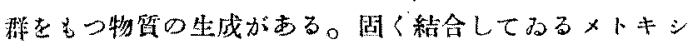

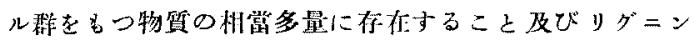

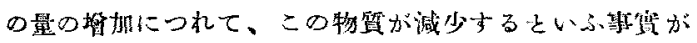
この假訳を市ならしめてわる。

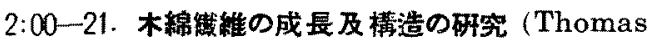

\section{Kerr )}

木綿綪維の一克壁の如き、成臣緗胞の壁は非常に薄く

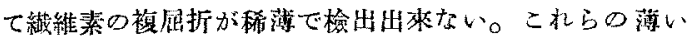

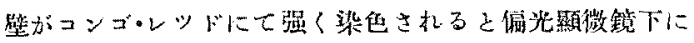
て数しい方向鼠性になる。他の代月の秋料にてる亦薄い

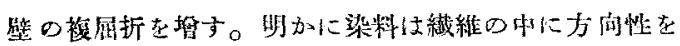

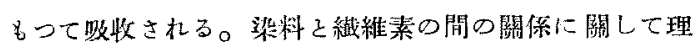

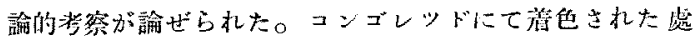

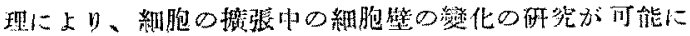

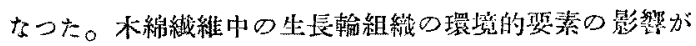

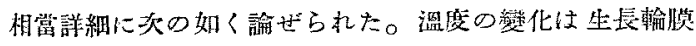

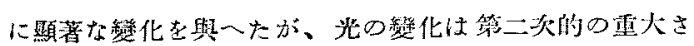

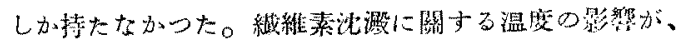

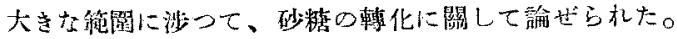

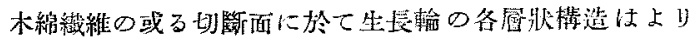
微細の集合原織維より成つてるることがわかる。

2:20-22. White oak wood の ray cell 中の綎維霜结 晶の配列(S. T. Gross, G. L.Clark, \& Gea. J. Ritter

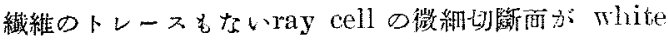
oak wood 加ら得ら扎た。そ机任 Van Beckum \& Ritter

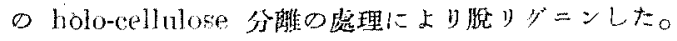

[Paper Trade J., $105(18): 127(1987)]$

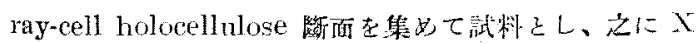

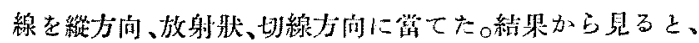

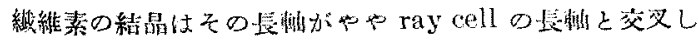

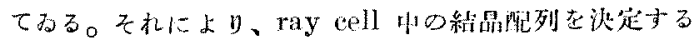
に信光に上る巴彩效果を利用して得な Ritter 及 Mitc-

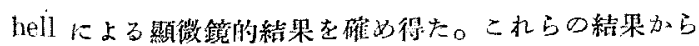

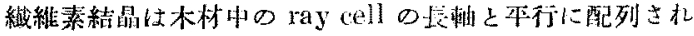
てるるといふ以前の莱一は閒造つてるることが明になつ to

2:40-23. Spierer Lensの像の生成方式 (Frederick F. Morehead.)

桥子の考一から、Spierer lens の真の分的能の爷式は

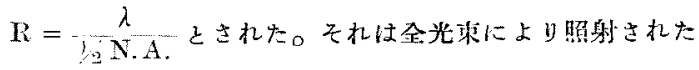

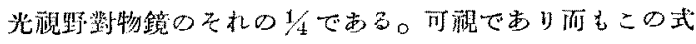

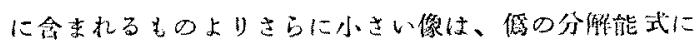
蹋せられる。此等の迴折像とこのレンズによる瀻維素の

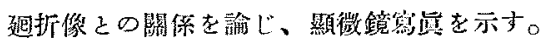

3.00-24. パルプ强度と緎維組瀻 (William Seifriz \& Charles H. Hock.)

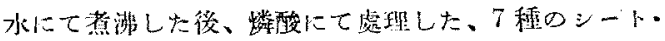

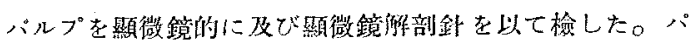

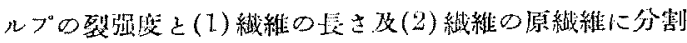

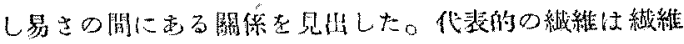

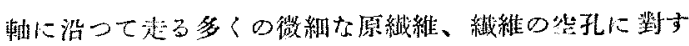

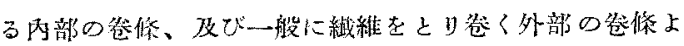
り成ることを知つた。

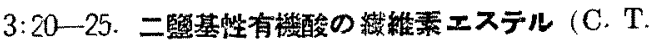

Malm \& Charles R. Foryce)

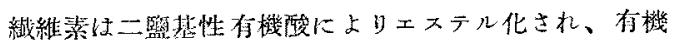

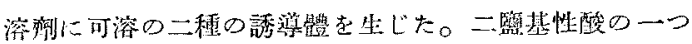

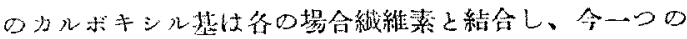

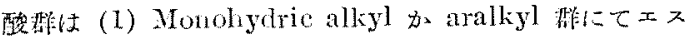

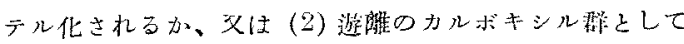

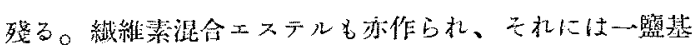

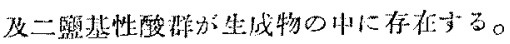

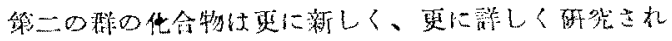
た。 cellulose acit dicarboxylate 0 水溶性整はアルカ

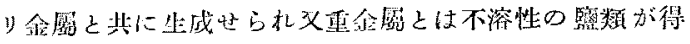
占礼机。

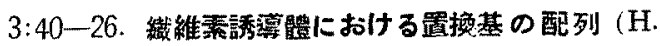
M. Spurlin.)

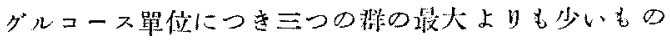




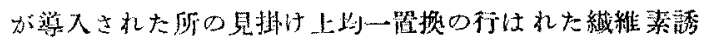

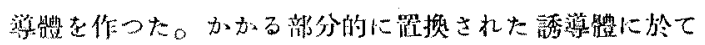

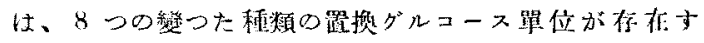

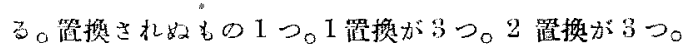

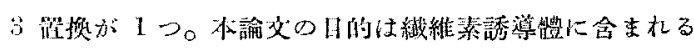

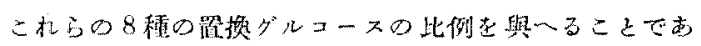

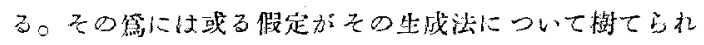
格ばなない。

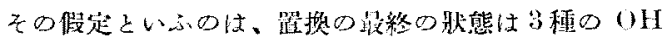

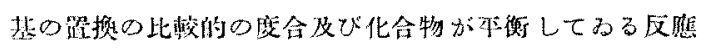

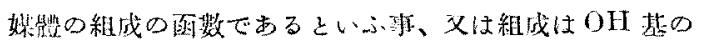

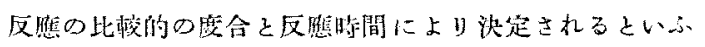
ずだる。

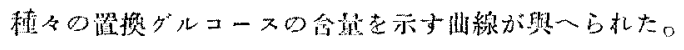

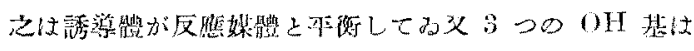

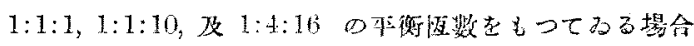
について行はれた。

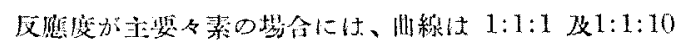

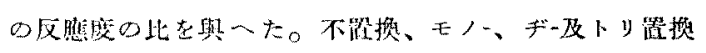

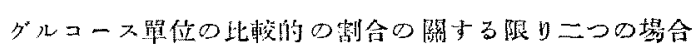

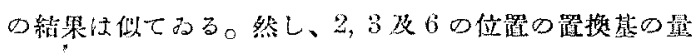

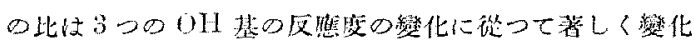
をた。

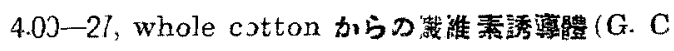
Holroyd \& F. K. Cameron)

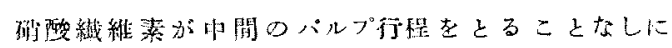

Whole cotton から㨁接に整喈し得ることが知られた。

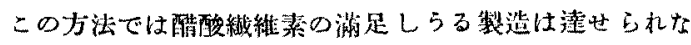
かつた。この研然により、明になつたことは Whole-

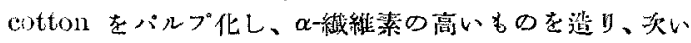

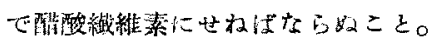

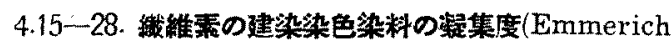
Valko)(Mannheim, Germany)

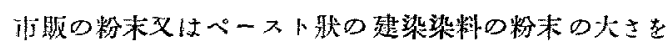

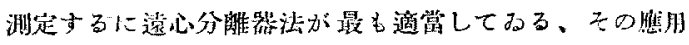
圭塳べる。

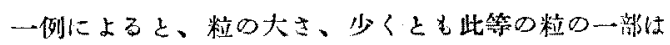
顯㣤鏡可視の限聚より小である。

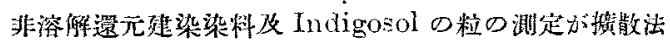

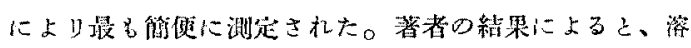

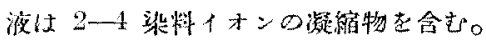

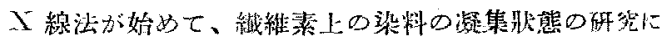

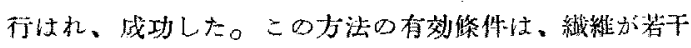

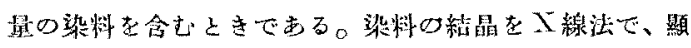

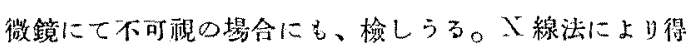
た結果によると、染料閒に次の漛な相違がある。

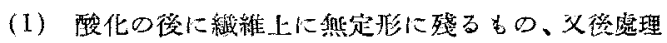

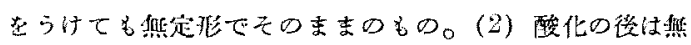

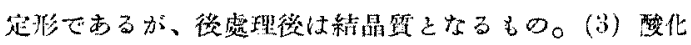

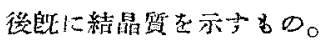

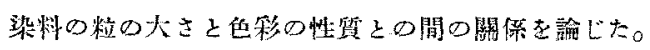

(1).上) 